\title{
Comparison of housing financing products in SR
}

\author{
Eva Nahalkova Tesarova, ${ }^{1, *}$ \\ ${ }^{1}$ University of Zilina, Faculty of Operation and Economics of Transport and Communications, \\ Department of Economics, Univerzitna 1, 01026 Zilina, Slovakia
}

\begin{abstract}
.
Research background: The paper describes the comparison and subsequent analysis of products for housing finance in the Slovak Republic through the use of financial resources from banks and savings companies. The development and boom of the real estate market in Slovakia was mainly due to new forms of financing, such as mortgage loans. At present, there are various combinations of credit products on the market with favorable declining interest rates, but also support from the state in the form tax bonus on paid interests or state premium for contractual savings for housing. The development of housing loans also has a significant impact on the Slovak economy. Rising household indebtedness is a problem beyond the financial sector.

Purpose of the article: Over-indebted households may have difficulty repaying loans in bad times or their consumption significantly reduce, which will exacerbate the process of resuming economic growth. The consequences of rising household indebtedness therefore need to be addressed from a wider perspective, including its economic-social impacts. The fundamental purpose of the article is to analyze the current possibilities of housing financing in the Slovak Republic and determine the most appropriate form.

Methods: In order to fulfill our stated goal, we apply a method of comparison, analysis and synthesis.

Findings \& Value added: Finally, we formulate our own view of which form of financing housing is the most suitable based on the examined parameters.
\end{abstract}

Keywords: mortgage loan; tax bonus on paid interests; contractual savings.

JEL Classification: $G 21 ; G 50 ; G 51$

\footnotetext{
*Corresponding author : tesarova@,stud.uniza.sk
} 


\section{Introduction}

The present is marked by ongoing changes in the financial sphere and the ongoing reforms are reflected in the area of credit. The development of the real estate market in Slovakia consists mainly in the support of new forms of financing, which include, among other things, financing though mortgages [1]. The rapidly growing mortgage market and the associated growth of household debt is associated with the crisis of the $2007-2009$ [2]. Debt expansion and housing boom have become a global aspect. Mortgage debt represents in European countries, around $80 \%$ [3]. Reserve Bank of Australia indicates that the largest component of Australia's household debt is housing loans, which account for $91.8 \%$ of the total [4], [5]. The level of mortgage indebtedness varies with the value and characteristics of the property, while individual mortgage interest rates depend on borrower characteristics [6]. China has introduced a housing finance system with unique characteristics: the system is operated through a housing commission political fund and a mortgage market from commercial banks. State commercial banks play a major role in the mortgage real estate market in China [7]. In Japan, the availability of housing loans has been gradually increasing, especially since 2000 . The increase in the availability of housing loans has been accompanied by a significant shift from fixed-rate to variable-rate housing loans. This is a cause for concern given the low level of financial literacy and the likelihood that interest rates on floating rate loans will rise as monetary policy tightens [8]. Financial risk is often perceived as the risk may default on debt payments [9]. In general, we can define credit risk as the probability of loss from a debtor's default [10].

An important indicator of Loan To Value is the percentage of the value of the property that can be financed through a bank loan. Some countries attach great importance to it. An alternative to the LTV ratio is the DTI ratio, which indicates the minimum level of expected ability of borrowers to repay debt [11].

Housing financing is divided into 4 systems [12]. The first is the retail deposit system in the United Kingdom, where the Financial Services Authority set up under the Financial Services Act 2000 is primarily responsible for regulation. In the United States, the second type of housing finance system is used, the mortgage security system. It is characterized by the existence of factors that shape regulatory policy, as regulatory responsibility for achieving the efficient and effective functioning of the residential property financing market is divided among many agencies at both the federal and state levels. In the United States, the market is dominated by housing loans with 15 and 30 year fixed rates. In Canada, Australia or Europe, mortgages with a variable interest rate generally predominate, with a fixed interest rate being available most often for a period of 3-5 years [13]. During the global crisis, the United States saw a sharp decline in residential property prices, coupled with a sharp rise in mortgage spreads, which led to a decline in loans to households and thus housing investment [14]. The German system of savings contracts Bauspar is another type of housing finance. Characteristics of Contractual Savings for Housing is a widespread and important product of household financing in continental Europe. It represents a significant share of housing finance in several European economies with a market penetration of 30-60\% in countries such as Germany, Austria, the Czech Republic and France. In addition to the mentioned countries, the savings product is also found in Belgium, Croatia, Hungary, Italy and the Slovak Republic. Inspired by the widespread and successful use of savings in Europe, countries such as China and India have been experimented with contractual savings on housing since 2003 and 2004 [15]. In Denmark, a specific type is housing finance through a system of mortgage bonds (hereinafter mortgage bonds). Mortgage bonds are supported by a strong legal framework with low risk for investors. 


\section{Methods}

First, we analyze individual forms of housing financing on the basis of acquired knowledge and available information of the Central Bank of the Slovak Republic. These will be housing loans, construction loans, interest rates and non-performing loans. Subsequently, we will perform an analysis of the real estate market in Slovakia. In the next step, we will continue the analysis of banking products, where we will focus on certain groups of the population (representative example). The information obtained by us from 12 banks and 3 building societies will be compared and, based on the comparison, a most suitable form of housing financing will be recommended.

\section{Results}

The development of housing loans has a significant impact on the Slovak economy and is becoming an increasingly popular choice of housing finance. For the period 2010 - 2019, the volume of housing loans, including mortgage loans, increased every year. In 2019, it was almost $€ 28$ billion. The latest statistics for the first quarter of 2020 tell us about further reaching the maximum. Banks were able to approve an even larger volume of loans, despite the constant tightening of conditions on the credit market. As of the last day of March, the volume of housing loans was $€ 28.63$ billion. We can argue that the continuing rapid growth of loans is due to ever-increasing demand supported by long-term growing credit capacity and lower interest rates. The year-on-year increase in loans from building savings was most pronounced in 2015 and 2017. The development of construction loans is characterized by a decrease. It was $€ 2.39$ billion in January and fell to $€ 2.37$ billion in March. Average interest rates have been falling sharply since 2010, with the exception of 2012. The year 2019 was marked by a easing of the ECB's monetary policy, given the prolonged period of low interest rates, which caused significant changes in interest rates pricing policy of banks. In July and August, under strong competitive pressure, average interest rates on housing loans fell from $1.5 \%$. a. at $1.3 \%$ p. a. As a result, net new loans and refinancing loans increased. Data for the first quarter of 2020 inform us about a further decline in average interest rates. However, in the following months interest rates rose due to the current market situation. The share of non-performing loans also belongs to the problem of housing loans. Due to the tightening of the LTV limit, losses in the event of insolvency have been significantly reduced. The probability of default in repaying the loan increases especially in times of crisis. According to financial analyst Búlik, but also others, the crisis associated with the coronavirus has pushed banks, not only in rising interest rates, but also in increasing measures against credit default. The problem with obtaining loans will be selfemployed and people working abroad. Despite the economic downturn and rising unemployment triggered by the crisis, the real estate market continued to show price records in the first quarter of 2020 , with year-on-year growth of $8.6 \%$, which is historically one of the highest growths.

In recent years, we have encountered the phenomenon of an enormous increase in the value of real estate compared to the income of the population. This fact puts pressure on the buyer and his reorientation to a smaller property. Currently, the growing demand of consumers for one-room and two-room apartments significantly affects their price. In economic centers and in places characterized by sufficient job opportunities, these two types of housing units make up the largest share of the total number of dwellings in current construction. When comparing prices per $\mathrm{m}^{2}$ for individual housing units, the most expensive were one-room apartments.

In the analysis, we focused on housing finance products of commercial banks in the current period. After a general analysis, we compared in a specific example of which bank 
offers the most advantageous loan for a potential client. The example consists of pre-crisis analysis and analysis of mortgage products at the time of the crisis. In addition to mortgage products, we also compare loans from building savings. However, through analysis and subsequent comparison, we found that these construction loans are not only timeconsuming (due to two-year savings), but also expensive. Interest rates are significantly higher compared to mortgage products. The most suitable form of housing financing is therefore a mortgage loan or a special-purpose housing loan.

\section{Table 1. Current offers of banks}

\begin{tabular}{|l|c|c|c|c|c|c|c|}
\hline & \multicolumn{3}{|c|}{ Before the crisis, data from January 2020 } & \multicolumn{3}{|c|}{ During the crisis, data from April 2020 } \\
\hline & Interest rate & Annuity & Interest & Interest rate & Annuity & Interest \\
\hline Bank 1 & $0,54 \%$ & $104007,60 €$ & $8007,60 €$ & $0,64 \%$ & $105537,60 €$ & $9537,60 €$ \\
\hline Bank 2 & $0,59 \%$ & $104770,80 €$ & $8770,80 €$ & - & - & - \\
\hline Bank 3 & $0,60 \%$ & $104922,00 €$ & $8922,00 €$ & - & - & - \\
\hline Bank 4 & $0,78 \%$ & $107701,20 €$ & $11701,20 €$ & $0,88 \%$ & $109263,60 €$ & $13263,60 €$ \\
\hline Bank 5 & $0,80 \%$ & $108010,80 €$ & $12010,80 €$ & $0,95 \%$ & $110365,20 €$ & $14365,20 €$ \\
\hline Bank 6 & $0,85 \%$ & $108792,00 €$ & $12792,00 €$ & $0,95 \%$ & $110365,20 €$ & $14365,20 €$ \\
\hline Bank 7 & $0,89 \%$ & $109422,00 €$ & $13422,00 €$ & $0,89 \%$ & $109422,00 €$ & $13422,00 €$ \\
\hline Bank 8 & $0,89 \%$ & $109422,00 €$ & $13422,00 €$ & $1,19 \%$ & $114199,20 €$ & $18199,20 €$ \\
\hline Bank 9 & $0,89 \%$ & $109422,00 €$ & $13422,00 €$ & $1,05 \%$ & $111952,80 €$ & $15952,80 €$ \\
\hline Bank 10 & $0,95 \%$ & $110365,20 €$ & $14365,20 €$ & $0,99 \%$ & $110998,80 €$ & $14998,80 €$ \\
\hline Bank 11 & $0,98 \%$ & $110840,40 €$ & $14840,40 €$ & $1,08 \%$ & $112431,60 €$ & $16431,60 €$ \\
\hline Bank 12 & $1,00 \%$ & $111157,20 €$ & $15157,20 €$ & $1 \%$ & $111157,20 €$ & $15157,20 €$ \\
\hline
\end{tabular}

In the example, we focused on individual parameters. The LTV height was $80 \%$. We are talking about the amount of credit provided to clients by banks. However, during the crisis, the two banks would not provide a loan of $80 \%$ of the LTV. We chose the loan repayment period for a period of 30 years. In addition to the statutory extraordinary installment, some banks offer the possibility of making other extraordinary installments. The next parameter we took into account was the annual average cost rate. The RPMN includes interest together with one-off or regular fees that are realized in connection with the drawdown of the loan, such as a fee for the provision of credit, insurance and others. Fees for depositing in the real estate cadastre and expert opinion are also taken into account. In addition to the above-mentioned parameters, we also examined the amount of the loan fee. As can be seen from the table in both situations (before and during the crisis), clients would pay the least interest in the Bank 1.

\section{Discussions}

When choosing a home loan, it is important to focus on a few points. The process of finding the right product and choosing it can be complicated in particular by the low level of the client's knowledge of housing loans or the time required for the process. Even in the current pandemic situation, a mortgage specialist is a good choice, especially because of negotiating favorable interest rates for the benefit of the client.

Many people look at the level of interest rates when choosing a product to finance their household, but this can be misleading, as not every favorable interest rate carries even the smallest costs associated with repaying a loan. We encourage to focus primarily on the annual percentage rate of charge, which reflects not only the interest itself, but also, for example, credit insurance in the event of default, account management fees and various one-off fees that a potential customer must pay and thus identify all related fees. 
The fixation of interest rates is also an important aspect. Most often, clients decide between a three-year or five-year fixation. Determining the length of fixation can be problematic, precisely because the level of interest rates in the financial market changes frequently. Applicants are advised to find out the current market situation in the first place. If a decrease in interest rates is expected in the following period, a shorter fixation period is advantageous; on the contrary, it is recommended to choose a longer fixation period when interest rates rise. On the other hand, with a longer fixation period, a higher interest rate is assumed with the certainty that the rate will not change for the entire length of the specified period. The reason for the higher interest rate with a longer fixation is the bank's consideration of the risk of interest rate development over a longer period. Shorter fixation has the advantage that the possibility of an extraordinary repayment when renewing the fixation is more frequent. The fundamental rule when providing mortgage loans or specialpurpose housing loans, which is valid, is that the shorter the maturity of the loan, the less the client overpays for it. If this period is longer, the client pays a smaller installment, but pays more on interest or other fees. We therefore recommend that the client determine the due date according to the amount of installments that he is able to repay and thus not overburden his budget. After the new one must also take into account the DTSI, the socalled financial cushion or reserve, which increased from the original $20 \%$ to $40 \%$. Therefore, if possible, the client should choose a shorter time. In the event of problems, this repayment period can be extended in agreement with the bank.

If the client meets the condition of age and amount of income, according to the Income Tax Act, he is entitled to a tax bonus on interest paid. At his request, the bank will provide him with an annual statement, according to which the tax bonus will be calculated. The client can apply for a period of 5 years.

When clients are considering refinancing, they need to be aware of whether a lower interest rate offer will pay off. Before choosing a refinancing, it is necessary to recalculate the exact parameters of a particular mortgage. The client should monitor the detailed balance of the refinancing process, not just nominal interest rates. Here, too, the client incurs costs that should be included in the overall balance sheet. We are talking mainly about the costs of early repayment of the original loan, a new expert opinion, a new proposal for the deposit of a lien in the real estate cadastre, cross - sell products and the cost of own time.

Banks currently require the client to deposit at least $20 \%$ of LTV. If the potential customer has its own sources of financing, it is more advantageous for him to apply for a mortgage loan with a lower LTV value. In the absence of own funds, the residual value of the property could be financed through a consumer loan, a construction loan or an intermediate loan. However, in the current situation, some banks do not want to provide real estate co-financing in the form of a consumer loan. One way can be a newlywed loan from the State Housing Development Fund. Clients (spouses) apply if they are under 35 years old and have been married for at least one year. Up to $€ 15,000$, the amount bears interest at $1 \%$ p. a. and its maturity is 15 years. We see the problem mainly in accessibility, as the fund has only a limited part of the funds it can lend.

\section{Conclusion}

In order to obtain financial resources for the purchase of real estate, it is necessary to meet certain specific conditions for each of the alternatives currently available on the credit market. The main goal was to analyze the current housing finance options in the Slovak Republic and choose the most appropriate form, which was a mortgage loan. It is characterized mainly by low interest rates without prior savings, but also by a relatively fast approval process. 


\section{References}

1. Spirkova, D. (2018). Housing Policy in the Slovak Republic, Housing, Amjad Almusaed and Asaad Almssad, IntechOpen, 21-39.

2. Mian, A., Sufi, A. (2015). House Of Debt: How They (And You) Caused The Great Recession, And How We Can Prevent It From Happening Again. Chicago: University of Chicago Press.

3. Van Gunten, T., Navot, E. (2018). Varieties Of Indebtedness: Financialization And Mortgage Market Institutions In Europe. Social Science Research, 70, 90-106.

4. Holland, Q.C.P., Liu, B., Roca, E., Salisu, A.A. (2020). Mortgage Asymmetric Pricing, Cash Rate And International Funding Cost: Australian Evidence. International Review of Economics \& Finance, 65, 46-68.

5. Taltavull, P., Worthington, A.C. (2012). The quarter century record on housing affordability, affordability drivers, and government policy responses in Australia. International Journal of Housing Markets and Analysis, 5(3), 235-252.

6. Dungey, M., Tchatoka, F.D., Yanotti, M.B. (2018). Endogeneity In Household Mortgage Choice. Economic Modelling, 73, 30-44.

7. Deng, Y., Fei, P. (2012). Mortgage Market, Character And Trends: China. International Encyclopedia of Housing and Home. 422-433.

8. Horioka, CH. Y., Niimi, Y. (2020). Was The Expansion Of Housing Credit In Japan Good Or Bad? Japan and the World Economy. 53, 100996.

9. Valaskova, K., Kliestik, T., Svabova, L., Adamko, P. (2018). Financial risk measurement and prediction modelling for sustainable development of business entities using regression analysis. Sustainability, 10(7), 2144.

10. Weissova, I., Kollar, B., Siekelova, A. (2015). Rating as a useful tool for credit risk measurement. Procedia Economics and Finance, 26, 278-285.

11. Morgan, P.J., Regis, P.J., Salike, N. (2019). LTV policy as a macroprudential tool and its effects on residential mortgage loans. Journal of Financial Intermediation, 37, 89103.

12. Flanagan, M. (2012). Mortgage Markets: Regulation And Intervention. International Encyclopedia of Housing and Home, 507-517.

13. Fuster, A., Vickery, J. (2015). Securitization And The Fixed-Rate Mortgage. The Review of Financial Studies, 28(1), 176-211.

14. Zhang, Y. (2019). Household debt, financial intermediation, and monetary policy. Journal of Macroeconomics, 59, 230-257.

15. Kirsch, S., Burghof, H.P. (2018). The Efficiency Of Savings-Linked Relationship Lending For Housing Finance. Journal of Housing Economics, 42, 55-68. 